\title{
Development Of Formulation And Production Technology Of Fish Pate For Therapeutic And Prophylactic Purposes
}

\author{
Galiya Kazhibayeva, Kuralay Issaeva, Akmaral Mukhamejanova, Mars Khayrullin, Dmitriy \\ Kulikov, Natalya Lebedeva, Vera Gribkova, Maksim Rebezov
}

\begin{abstract}
This paper presents the method of preparation of fish pate from pike or bream and additionally comprising pumpkin, vegetable oil, seaweed. Detailed fish pate production scheme is described. The developed fish pate has good sensory properties with high nutritional value. The protein content varied from 17.1 to $18.0 \%$ with high presence of essential amino acids, such as valine $97.5 \mathrm{mg} / 100 \mathrm{~g}$, isoleucine $93.8 \mathrm{mg} / 100 \mathrm{~g}$, threonine $79.1 \mathrm{mg} / 100 \mathrm{~g}$ and tryptophan $18.4 \mathrm{mg} / 100 \mathrm{~g}$. Scientifically grounded fish pate formulation and production technology can lead to enrich human diet with healthy nutrients and improve human well-being and health conditions.
\end{abstract}

\section{Keywords: amino acid, bream, fish, pate, pumpkin}

\section{INTRODUCTION}

In view of the fact that in ecologically unfavorable regions of Kazakhstan radiation damage is accompanied by serious metabolic disorders, as a result in the human body there is a deficiency of micronutrients in nutrition, namely: vitamins (C, P, PP, A, E, B), macro - and microelements (calcium, magnesium, zinc, selenium, iodine), dietary fibers, essential amino acids and other compounds, the task was to develop new types of functional foods for therapeutic and prophylactic purposes (Okuskhanova et al. 2017, Kakimov et al. 2017). The basis of preventive nutrition the aim is to correct the deficiencies of micronutrients by introducing necessary nutrient substances with radioprotective properties,

The preventive orientation of the recommended diets is achieved by inclusion in the set of products, the richest in vitamins, antioxidants, as well as suppliers of calcium, iodine and fluorine, polyunsaturated fatty acids (fish, vegetable oil) and as sources of mineral substances in the

Revised Manuscript Received on April 19, 2019.

Galiya Kazhibayeva, S. Toraighyrov Pavlodar State University, Kazakhstan, Central Asia.(Email: stat.stat2016@yandex.ru)

Kuralay Issaeva, S. Toraighyrov Pavlodar State University, Kazakhstan, Central Asia.

Akmaral Mukhamejanova, S. Toraighyrov Pavlodar State University, Kazakhstan, Central Asia.

Mars Khayrullin, K.G. Razumovsky Moscow State University of technologies and management, (the First Cossack University); Russian Academy of Staffing of Agro-Industrial Complex, Moscow, Russia

Dmitriy Kulikov, K.G. Razumovsky Moscow State University of technologies and management, (the First Cossack University); Moscow, Russia.

Natalya Lebedeva, K.G. Razumovsky Moscow State University of technologies and management, (the First Cossack University);

Vera Gribkova, K.G. Razumovsky Moscow State University of technologies and management, (the First Cossack University);

Maksim Rebezov, K.G. Razumovsky Moscow State University of technologies and management, (the First Cossack University); Ural State Agrarian University, Yekaterinburg, Russia diets of introduced seafood (seaweed). Food fibers supply the body with vegetables (pumpkin, etc.) (Zhumanova et al. 2018, Storebakken et al. 1998).

The functional orientation of the products is given mainly by biologically active additives introduced into the formulations. One of the additional sources of protein and biologically active additives (BAA) is vegetable raw materials. Combined products are created on the basis of a combination of animal proteins with vegetable proteins (Kakimov et al. 2017, Tokhtarov et al. 2016).

The authors developed a new fish product, the following raw materials were chosen as functional ingredients for a new type of fish pate: freshwater fish (bream or perch), seaweed (kelp), pumpkin, vegetable oil, etc. (Kazhibayeva and Makhmetzhanova 2012).

In Pavlodar and East Kazakhstan region relatively high content of freshwater fish (Irtysh river, Zaisan island, Shulba reservoir, etc.) compared to other types of meat (beef, pork, etc.) its cost is much available to the public.

Fish is rich source of protein, vitamins and minerals, but contains less fatm especially presented with polyunsaturated fatty acids. The fish contains a large amount of potassium, magnesium and phosphorus. In the liver of many fish a high content of vitamins a, D, E. Fish and seafood (sea cabbage) are rich in iodine and fluorine, they contain other usefu elements. Without all these additives, the human body would not be able to function normally. Fish proteins are more easily digested and absorbed by the body. Fat is useful, it contains a lot of vitamin a and a large number of essential polyunsaturated fatty acids (Rekhina and Novikova 1986, Krasina et al. 2017).

The value of fish as a food product is determined by the presence of high-grade proteins, easily digestible fats, as well as a significant content of vitamins and minerals in its meat. As a rule, fish proteins are complete, they contain all essential amino acids and are absorbed by the human body by $98 \%$. The important physiological significance of fish meat is determined by its macro-and microelementsphosphorus, calcium, potassium, sodium, magnesium, sulfur, chlorine, iron, copper, manganese, cobalt, zinc, iodine, bromine, fluorine, etc. (Najib et al. 2016).

The use of fish and seafood as a source of protein in nutrition promotes normal growth and mental development 
of children, prevents hematopoietic disorders, metabolism of fats and vitamins, as well as increases the body's resistance to infections, colds and some other diseases. Fish proteins have a very important ability to bind some toxic substances in hard-soluble complexes, which are then excreted from the body (Lago et al. 2017, Truc 2017).

\section{MATERIALS AND METHODS}

Among the large number of freshwater fish for research were selected fish (bream and perch), due to the largest catch in the East Kazakhstan region, high nutritional value and low cost. Thus, the nutritional value of fish-bream is \%: the amount of moisture $-76,4$; the amount of protein $-18,1$; the amount of fat $-4,3$; minerals $-1,2$.

Adding pumpkin to fish minced meat enriches the product with useful nutrients. Pumpkin is rich in dietary fibers that promote digestion of food in the gastrointestinal tract, betacarotene, which it contains several times more than carrots. A lot of pumpkin minerals involved in hematopoiesis (iron, copper, cobalt, zinc). Pumpkin is also rich in zinc salts, contributing to potency and vitamin $\mathrm{E}$, which helps to slow the aging process. Due to the high content of trace elements and vitamins, pumpkin is recommended for all cardiovascular diseases, edema, anemia and obesity.

Chemical composition of pumpkin, \%: mass fraction of moisture $-90,3$; mass fraction of protein $-1,0$; mass fraction of fat $-0,1$; carbohydrates $-5,9$; mass fraction of minerals 2,7 .

In the last time given favor of and the rich chemical composition pumpkin it is have become widely apply in food technology. In functional production, vegetables are recommended to be used in the form of powder. Pumpkin powder can be attributed to biologically active additives. There is no doubt the use of pumpkin powder in the treatment of diseases of the gastrointestinal tract, cardiovascular system, kidneys, liver and bladder. Invaluable benefits of pumpkin in the fight against anemia, insomnia, as well as intoxication, which is accompanied by vomiting.

The use of vegetable oil instead of animal (butter) significantly enriches the finished product polyunsaturated fatty acids (oleic, linoleic, arachidonic).

The experimental research was proposed three possible formulations of fish paste, for control was chosen fish pie «Parus» (table 1).

Table 1. Formulations of the new fish paste

\begin{tabular}{|c|c|c|c|c|}
\hline \multirow[t]{2}{*}{ Name of raw material } & \multicolumn{4}{|c|}{ Raw material in $\mathrm{kg} / 100 \mathrm{~kg}$ product } \\
\hline & Control & I option & II option & III option \\
\hline Pike & 63 & - & - & - \\
\hline Bream & - & 61 & 56 & 51 \\
\hline Carrot & 23 & - & - & - \\
\hline Pumpkin & - & 20 & 20 & 20 \\
\hline Seaweed (kelp) & - & 5 & 10 & 15 \\
\hline Vegetable oil & - & 7 & 7 & 7 \\
\hline Butter & 6 & - & - & - \\
\hline Fish broth & 4 & 4 & 4 & 4 \\
\hline Dillweed & 4 & 4 & 4 & 4 \\
\hline Total: & 100 & 100 & 100 & 100 \\
\hline Spices, g/100 kg produc & & & & \\
\hline
\end{tabular}




\begin{tabular}{|l|c|c|c|c|}
\hline Table salt & 2000 & 2000 & 2000 & 2000 \\
\hline Black pepper-ground & 20 & 20 & 20 & 20 \\
\hline Muscat & 20 & 20 & 20 & 20 \\
\hline
\end{tabular}

Technological process: in the preparation of fish pate used bone-cleared fish (bream), as a vegetable raw material used peeled pumpkin and chopped sea cabbage (kelp). Vegetable oil was used as a mixture.

First, prepare minced fish, which is frozen or chilled fish deportiruyut in the water temperature no higher than $150 \mathrm{C}$ at a ratio of fish and water of at least 1:2 to achieve in the thickness of the meat temperature below $-10^{\circ} \mathrm{C}$, then wash the fish in running water, removes excess water. Prepared fish carcasses are cleaned, cut, while removing inedible parts of the fish: the tail, dorsal and anal fins, Gill covers, eyes, intestines and gallbladder. Then, the separated fish is washed in running water, small fish in General, and large fish is cut into pieces and placed in a container, salt is added to extract the water contained in the fish.

The technological process of production of a new fish paste is based on traditional technology of the producer of a fish paste «Parus». The difference is the introduction of functional ingredients (fish bream, kelp, pumpkin) in the technological scheme (figure 1).

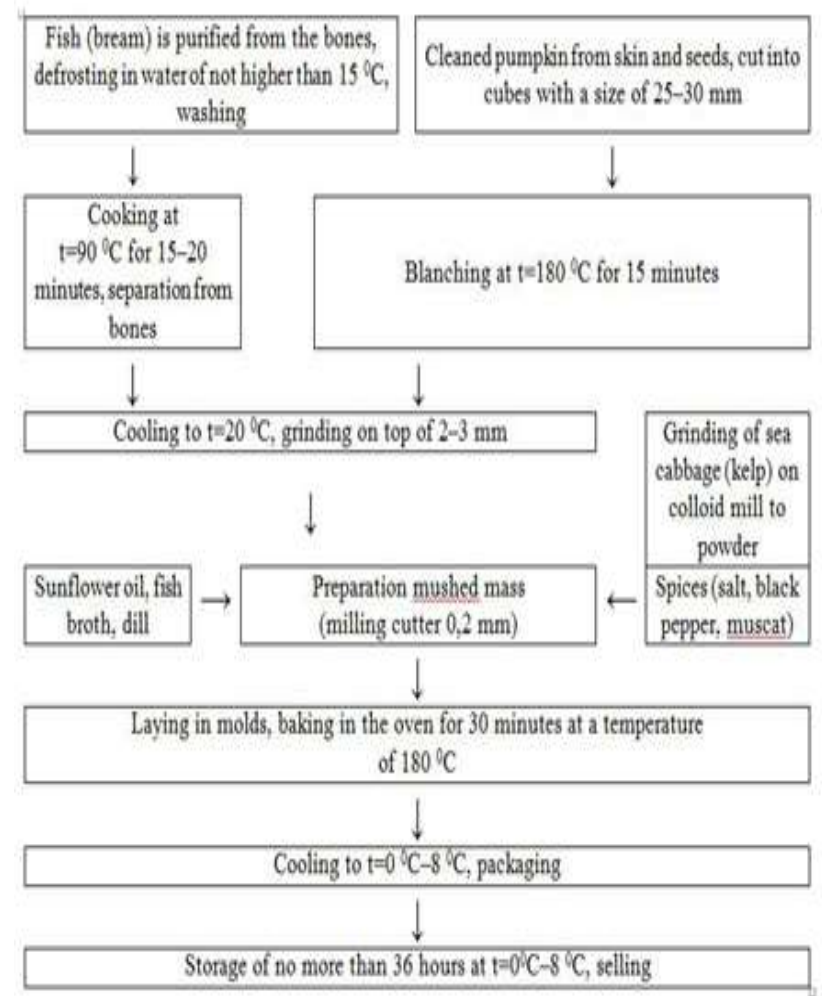

Fig. 1. Technological scheme of production of fish paste

The fish is cooked at a temperature of 90 0C for 15-20 minutes, separated from the large bones, cooled to a temperature $(\mathrm{t}=200 \mathrm{C})$. Chilled fish is crushed to a minced consistency on a wolf with a diameter of $2-3 \mathrm{~mm}$. Pumpkin peeled, crushed into cubes of $25-30 \mathrm{~mm}$, blanching at $\mathrm{t}=180$ 0C for 15 minutes. Laminaria (kelp) is ground in a colloid mill to a powder. Salt cooking food and black pepper-ground, sifted.

According to the recipe, all ingredients are mixed in the composition of the paste: minced fish, crushed seaweed (kelp), processed pumpkin, vegetable oil, dill, spices. The paste mass is subjected to fine grinding in the cutter to a particle size of not more than $0.2 \mathrm{~mm}$, which is necessary for the formation of a homogeneous mass, achieving a pasty smeared consistency.

\section{RESULTS AND DISCUSSION}

Organoleptic characteristics of fish pate are given in table 2

Table 2. Organoleptic characteristics of fish pate

\begin{tabular}{|l|l|}
\hline \multicolumn{1}{|c|}{ Name of indicator } & \multicolumn{1}{|c|}{ Characteristic } \\
\hline Appearance & $\begin{array}{l}\text { Paste mass in parchment with clean, dry surface } \\
\text { without damage to the shell, without spots, } \\
\text { flows of minced meat and slips }\end{array}$ \\
\hline Consistency & Tender,juicy, spotting \\
\hline Condition & $\begin{array}{l}\text { Homogeneous, finely chopped, uniformly mixed } \\
\text { mass without fibrous and not crushedbones. }\end{array}$ \\
& Allowed-the presence of small particles of \\
spices
\end{tabular}

The paste mass is tightly Packed into molds, greased with vegetable oil, preventing the formation of voids and pores. Forms with a capacity of $0,5-1,0 \mathrm{~kg}$ with pate set in the oven, where it is baked for 30 minutes at $1800 \mathrm{C}$. Baking is considered complete when the temperature in the center of the mass reaches $700 \mathrm{C}$. The finished pastes are cooled to a temperature of $00 \mathrm{C}-80 \mathrm{C}$ in the air, spread out of the mold, wrapped in parchment, podpergament or polyethylene film 
International Conference on Recents Advancements in Engineering and Technology (ICRAET-18) |15th and 16th March 2019|Siddhartha Institute of Technology \& Sciences, Telangana, India.

and directed to the implementation. Store pastes for no more than 36 hours at a temperature of $00 \mathrm{C}-80 \mathrm{C}$ and relative humidity of $80 \%-85 \%$.

Comparative nutritional value of fish pate of test samples with control is presented in table 3 .

Table 3. Nutritional value of fish pastes

\begin{tabular}{|c|c|c|c|c|}
\hline \multirow[t]{2}{*}{ Indicators } & \multirow{2}{*}{$\begin{array}{l}\text { Control } \\
\text { fish pate } \\
\text { eParuss }\end{array}$} & \multicolumn{3}{|c|}{ Fish pate (experience) } \\
\hline & & I option & II option & III option \\
\hline Mass fraction of protein $\%$ & 16,8 & 18,0 & 17,7 & 17,1 \\
\hline Mass fractiots of tat. $\%$ & 18,0 & 11.1 & 9.9 & 8,2 \\
\hline $\begin{array}{l}\text { Mass fraction of mineral } \\
\text { substances, } \%\end{array}$ & 2,45 & 3,2 & 2,7 & 2,5 \\
\hline Mass fraction of moisture, $\%$ & 62.75 & 67,7 & 69,7 & 72.2 \\
\hline Energy value, keal & 239 & 193 & 189 & 178 \\
\hline
\end{tabular}

The results of the study of the nutritional value of prototypes in comparison with the control show a significant increase in the mass fraction of protein, minerals and a lower content of the mass fraction of fat, as a result, the energy value of the prototypes is lower than the control value, which indicates a high nutritional value and low calorie fish paste. The fish pate prepared according to the light recipe meets all the requirements of proper nutrition. Organoleptic evaluation was carried out on a 5-point system, the indicators were taken into account: appearance, color, smell, aroma, taste, consistency, juiciness, according to which the prototypes were not inferior to the control, and some even surpassed (aroma, taste, consistency, juiciness).

Thus, this method allows to obtain a natural low-calorie fish paste with a balanced chemical composition, enriched with minerals and dietary fibers, with high organoleptic characteristics and a relatively low cost.

Research of food, biological value, mineral composition and microstructure of fish pates. With the help of an electronic microscope JSM-6390, studies of the (elemental) mineral composition of fish pastes were carried out. The diagram of the mineral composition of the fish paste indicates a significant mineral content $(\mathrm{Mg}, \mathrm{P}, \mathrm{K}, \mathrm{Ca}$, etc.). samples the elemental composition significantly exceeds that in the control samples. The histogram of the mineral composition of the fish paste is presented in accordance with figure 2 .

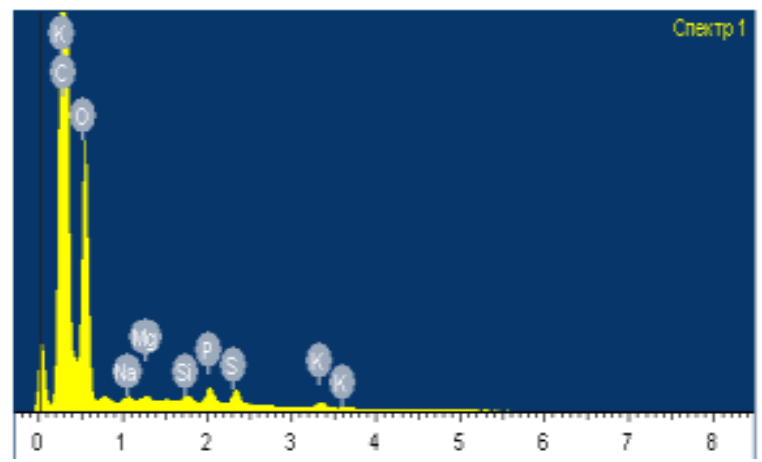

Fig. 2. Histogram of the mineral composition of fish paste Analyzing the results, it was noted that in the experimental

The diagram shows that in the experimental sample the content of minerals: phosphorus - $12 \mathrm{mg}$, calcium - $7 \mathrm{mg}$ and potassium - $12 \mathrm{mg}$ is much higher than in the control. The new fish paste contains a large amount of minerals. As you know, minerals play a very important role in the normal functioning of the human body. They are part of all cells, organs and tissues, intracellular and extracellular fluids of the body, molecules of many biologically active organic substances, are actively involved in the regulation of metabolic processes. The breakdown and synthesis of proteins, carbohydrates and lipids largely depend on the participation of mineral elements in these processes. The comparative mineral composition of the test and control sample is presented in accordance with figure 3.

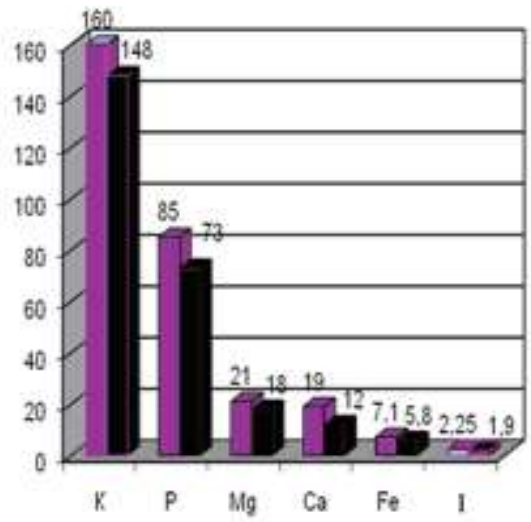

Paste "Parus"

Paste "Mukhit"

Fig. 3. Comparative mineral composition of the test and control sample

Table 4. Content of minerals and functional ingredients

\begin{tabular}{|c|c|c|c|}
\hline \multirow{2}{*}{ Indicators } & \multicolumn{3}{|c|}{ Content, mg per $100 \mathrm{~g}$} \\
\hline & Fish-bream & Pumpkin & Sea kale \\
\hline \multicolumn{4}{|l|}{ Macronutrients, mg } \\
\hline Potassium & 294,0 & 204 & 970 \\
\hline Calcium & 19,0 & 25 & 40 \\
\hline Magnesium & 23,0 & 14 & 170 \\
\hline Phosphorus & 202,0 & 25 & 55 \\
\hline Iron & - & - & 16 \\
\hline Sodium & - & - & 520 \\
\hline \multicolumn{4}{|l|}{ Trace elements, mg } \\
\hline Todine & 0,011 & 1 & 160000 \\
\hline Cobalt & 0,002 & 1 & \\
\hline Sodium & - & 4 & \\
\hline Sulfur & - & 18 & \\
\hline Phosphorus & - & 25 & \\
\hline Chlorine & - & 19 & \\
\hline Manganese & - & - & 0,6 \\
\hline
\end{tabular}


The data given in table 4 show that the composition of the fish-bream contains a sufficient amount of minerals. Based on the data in the chart, you can see that the amount of calcium and phosphorus has increased significantly. Thanks to the content of vitamins, macro and microelements and other nutrients necessary for vital activity of our organism, fish is an irreplaceable component of a diet of the person.

The amino acid composition of fish pastes is presented in table 5.

Table 5. Content of essential amino acids in fish pastes

\begin{tabular}{|c|c|c|c|c|c|}
\hline \multirow{2}{*}{$\begin{array}{l}\text { Essential } \\
\text { amino acid }\end{array}$} & \multirow{2}{*}{\begin{tabular}{|c|}
${ }^{*} \mathrm{FAO} / \mathrm{WHO}$ \\
recommended \\
protein level, \\
$\mathrm{mg} / 100 \mathrm{~g}$
\end{tabular}} & \multicolumn{2}{|c|}{${ }^{*}$ Pate «Parus») (control) } & \multicolumn{2}{|c|}{ Fish pate (experience) } \\
\hline & & $\begin{array}{c}\mathrm{mg} / 100 \mathrm{~g} \\
\text { amount of } \\
\text { proteins in } \\
\mathrm{AC}\end{array}$ & $\begin{array}{l}\text { Amino } \\
\text { acid } \\
\text { score, \% }\end{array}$ & $\begin{array}{c}\mathrm{mg} / 100 \mathrm{~g} \\
\text { amount of } \\
\text { proteins in } \\
\mathrm{AC}\end{array}$ & $\begin{array}{l}\text { Amino } \\
\text { acid } \\
\text { score, \% }\end{array}$ \\
\hline Valine & 50,0 & 90,0 & 180,0 & 97,5 & 195,0 \\
\hline Isoleucine & 40,0 & 70,0 & 175,0 & 93,8 & 234,5 \\
\hline Leucine & 70,0 & 130,0 & 185,7 & 139,8 & 199,7 \\
\hline Lysine & 55,0 & 150,0 & 272,7 & 161,9 & 294,4 \\
\hline Methionine & 35,0 & 50,0 & 142,9 & 53,4 & 152,6 \\
\hline Threonine & 40,0 & 65,0 & 162,5 & 79,1 & 197,8 \\
\hline Tryptophan & 10,0 & 16,5 & 165,0 & 18,4 & 184,0 \\
\hline Phenylalarine & 60,0 & 58,0 & 106,7 & 68,1 & 113,5 \\
\hline * - literature da & & & & & \\
\hline
\end{tabular}

In order to determine the biological value of a product, we need to be aware of the amount of essential amino acids that come from food only and are not synthesized in the body. If the number of amino acids corresponds to the aminogramme or closest to this result or to the "ideal protein", the more valuable protein is considered.

\section{CONCLUSION}

Finally, meat and fish product line expansion and offering the new formulation and method of fish pate production is the relevant and urgent issue in modern food industry. Developed fish pate with vegetable raw materials is rich in protein and mineral elements, has high nutritional and biological value and can be classified as functional food products.

\section{REFERENCES}

1 Okuskhanova E, Smolnikova F, Kassymov S, Zinina O, Mustafayeva A, Rebezov M, Rebezov Y, Tazeddinova D, Galieva Z, Maksimiuk N (2017) Development of minced meatball composition for the population from unfavorable ecological regions Annual Research and Review in Biology, 13 (3).

2 Kakimov A, Zharykbasov Y, Kakimova Z, Yessimbekov Z, Mirasheva G, Baybalinova M, Smirnova I (2017) Specific activity of Cs-137 in milk of Semey region of East Kazakhstan area. Annual Research and Review in Biology, 12(5): ARRB-33391.
3 Zhumanova G, Rebezov M, Assenova B, Okuskhanova E (2018) Prospects of using poultry by-products in the technology of chopped semi-finished products. International Journal of Engineering and Technology(UAE), 7 (3.34): 495-498.

4 Storebakken T, Shearer KD, Roem AJ (1998) Availability of protein, phosphorus and other elements in fish meal, soy-protein concentrate and phytase-treated soy-protein-concentrate-based diets to Atlantic salmon, Salmo salar. Aquaculture, 161(1-4): 365-379.

5 Kakimov A, Suychinov A, Mayorov A, Yessimbekov Z, Okuskhanova E, Kuderinova N, Bakiyeva A (2017) Meat-bone paste as an ingredient for meat batter, effect on physicochemical properties and amino acid composition. Pakistan Journal of Nutrition, 16 (10): 797 804.

6 Tokhtarov Z, Amirkhanov K, Kassenov A, Kakimov M, Orynbekov D, Moldabayeva Z (2016) Mineral composition of sea buckthorn. Research Journal of Pharmaceutical, Biological and Chemical Sciences, 7 (4): 1373-1377.

7 Kazhibayeva GT, Makhmetzhanova ZhS (2012) Patent \#28182 Republic of Kazakhstan. Method of fish pate preparation. Date of publication 07.02.2012.

8 Rekhina NI, Novikova MV (1986) Production of minced meat from small-sized fish. Rybnoe hozjajstvo, 2 ; 9-10.

9 Krasina IB, Tarasenko NA, Nikonovich YN, Krasin PS (2017) Features of chemical composition of aromatic raw materials CO2-meals. Journal of Pharmaceutical Sciences and Research, 9(4): 332-337.

10 Najib MS, Zamberan NH, Zahed N, Halim FA, Zahari MF, Mamat WM, Manap H (2016) Fish quality study using odor-profile case-based reasoning (CBR) classification technique. ARPN Journal of Engineering and Applied Sciences, 11(10): 1-6.

11 Lago AM, Vidal AC, Schiassi MC, Reis T, Pimenta C, Pimenta ME (2017) Influence of the addition of minced fish on the preparation of fish sausage: effects on sensory properties. Journal of food science, 82(2): 492-499.

12 Truc TT (2017) Improving the physicochemical properties of snakehead fish (channastriata) sausage by protease from its viscera. Vietnam Journal of Science and Technology, 55(5A): 83-91. 